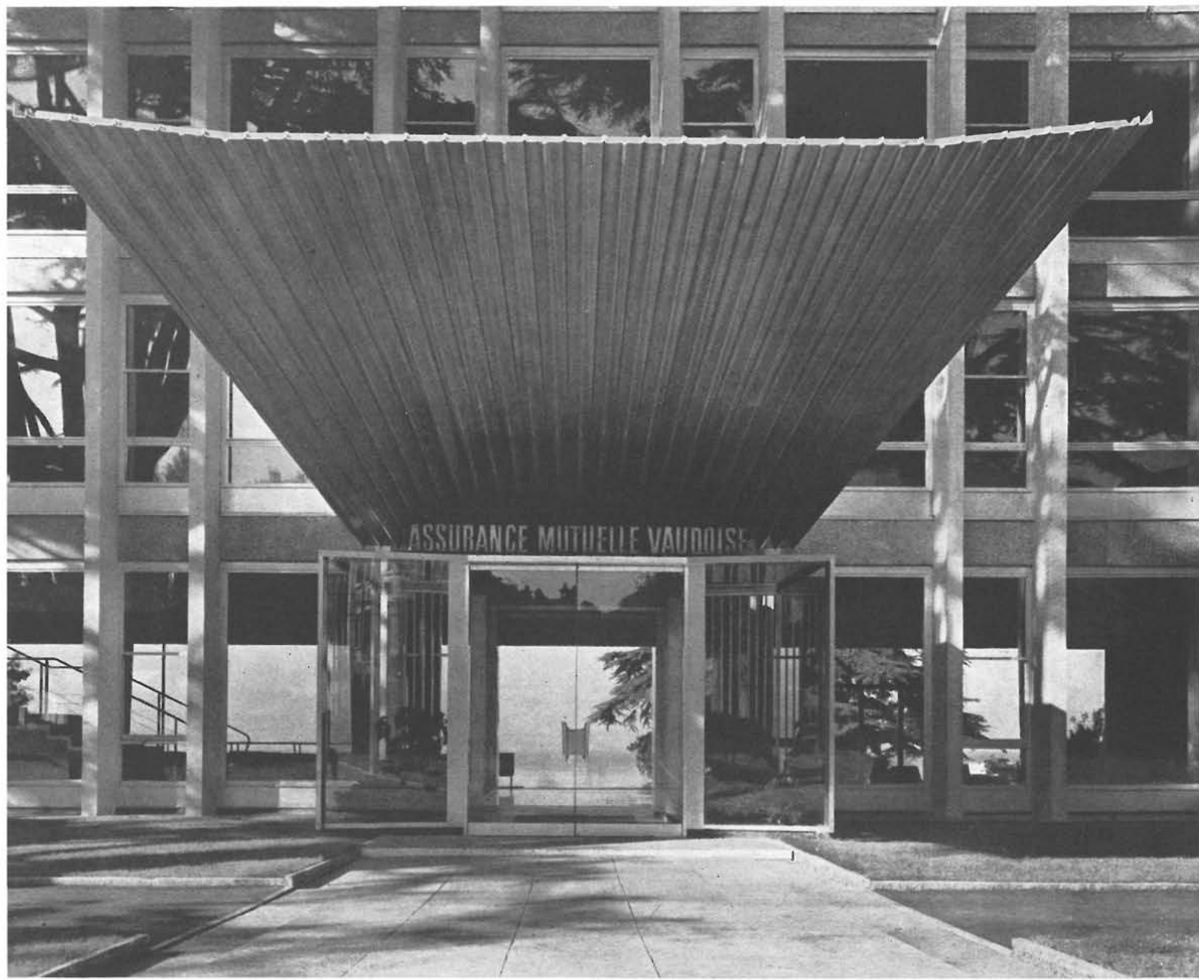

\title{
edificio le cèdre
}

J. TSCHUMI, arquitecto

Este importante edificio administrativo está situado en Lausana, formando parte de un magnífico paisaje, en las orillas del lago Leman, en cuyo terreno se elevan las soberbias masas de unos cedros centenarios que había que conservar a toda costa, procurando armonizar el edificio y la naturaleza. En el centro del parque se conserva también otro cedro majestuoso que cobija un antiguo pabellón octogonal, único vestigio del pasado. 


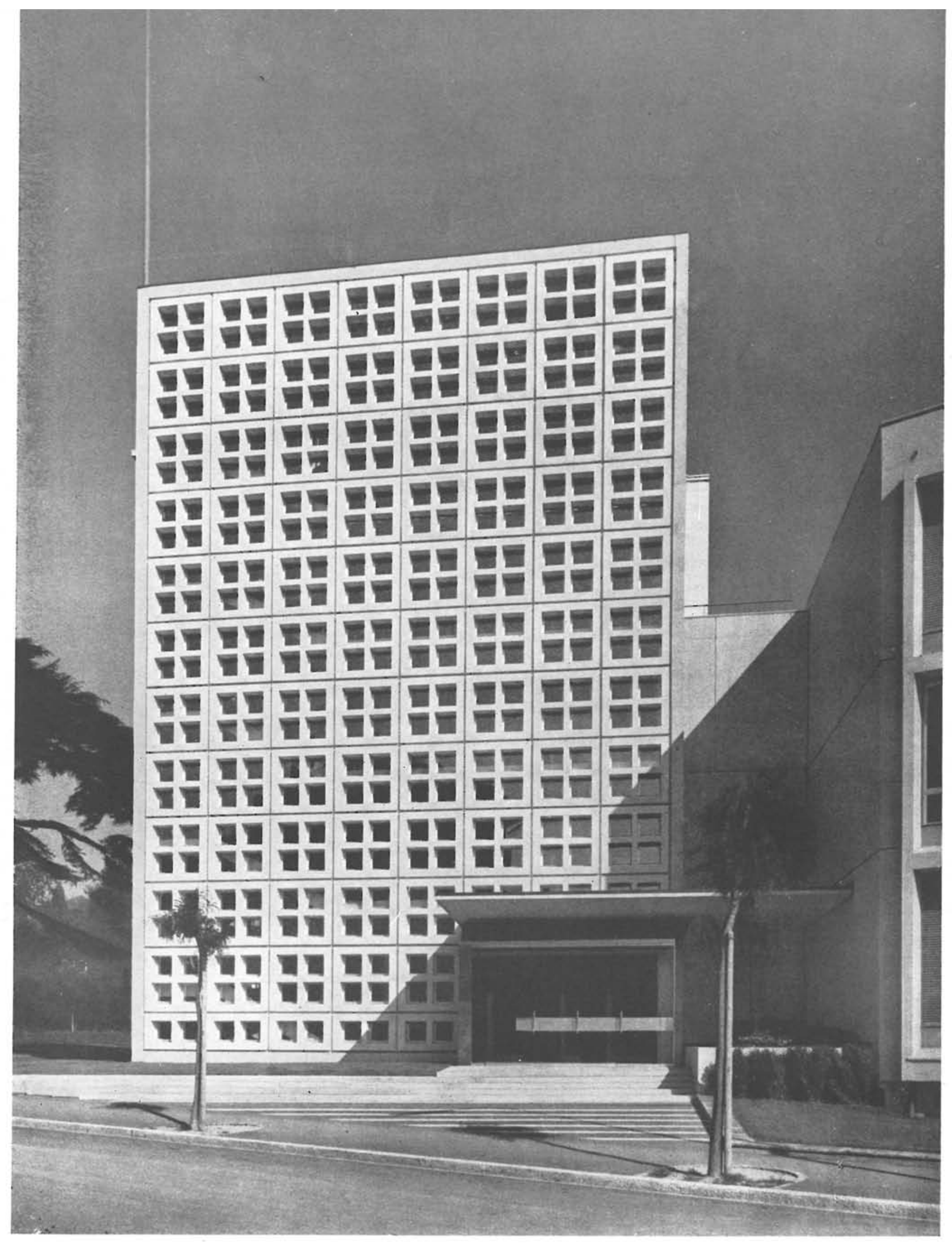

Reticulado de la fachada Oeste. 


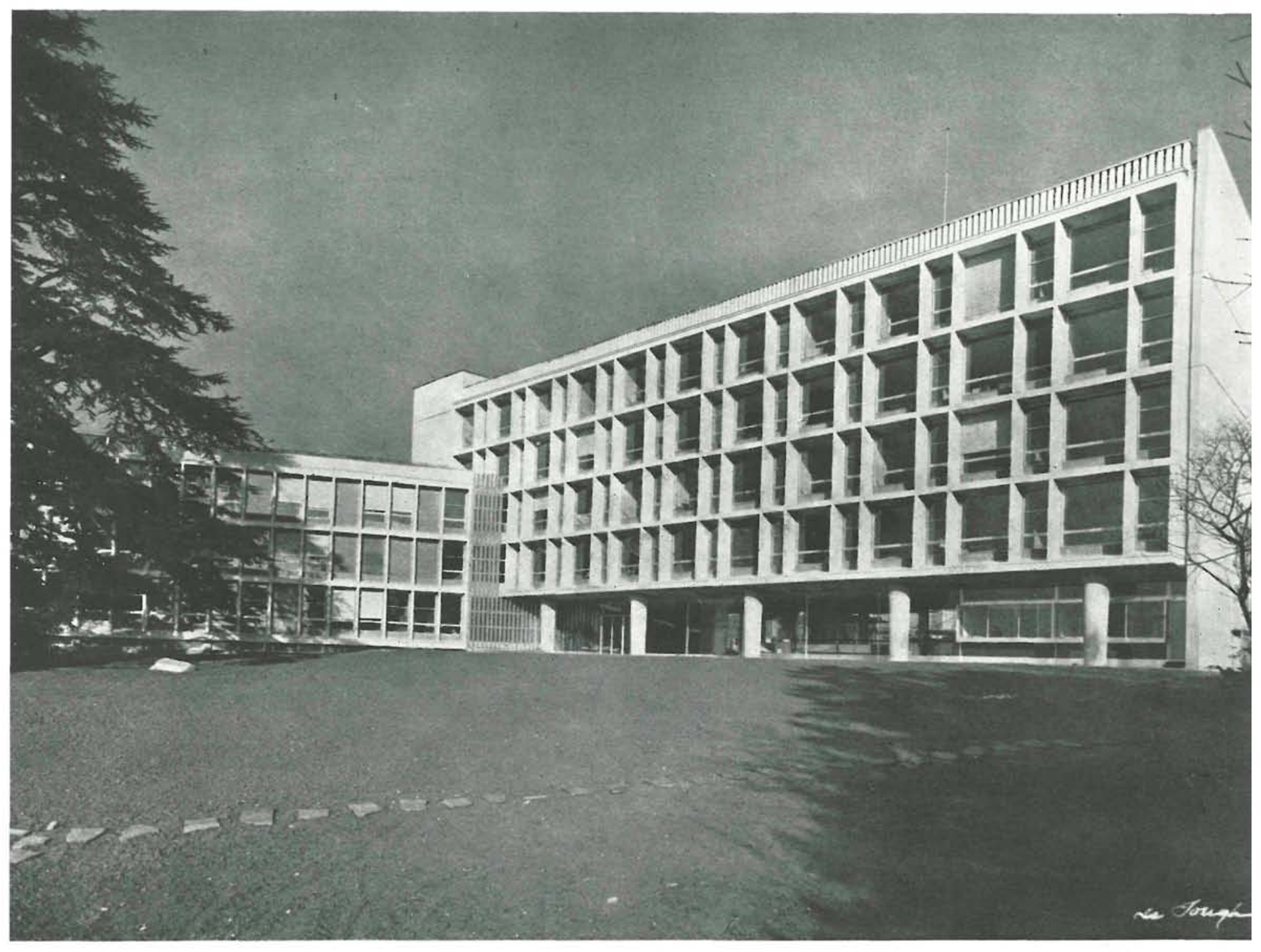

Se ha estudiado la composición y disposición de masas, de modo que nunca quede oculto el hermoso panorama, adoptando la forma de una ele de brazos abiertos, con tres entradas: dos por las fachadas $\mathrm{N}$. y O. para personal y una por la fachada menos importante, utilizando la pendiente del terreno para vehículos.

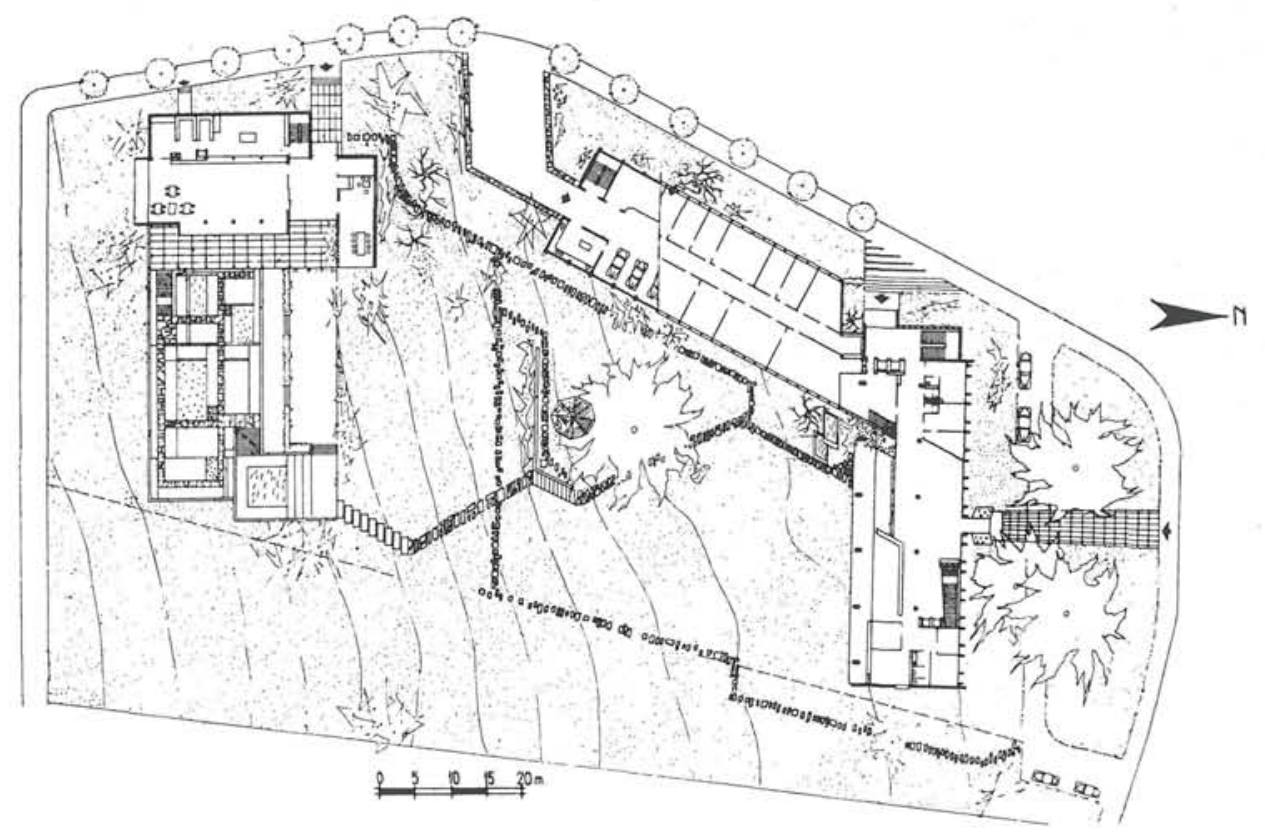




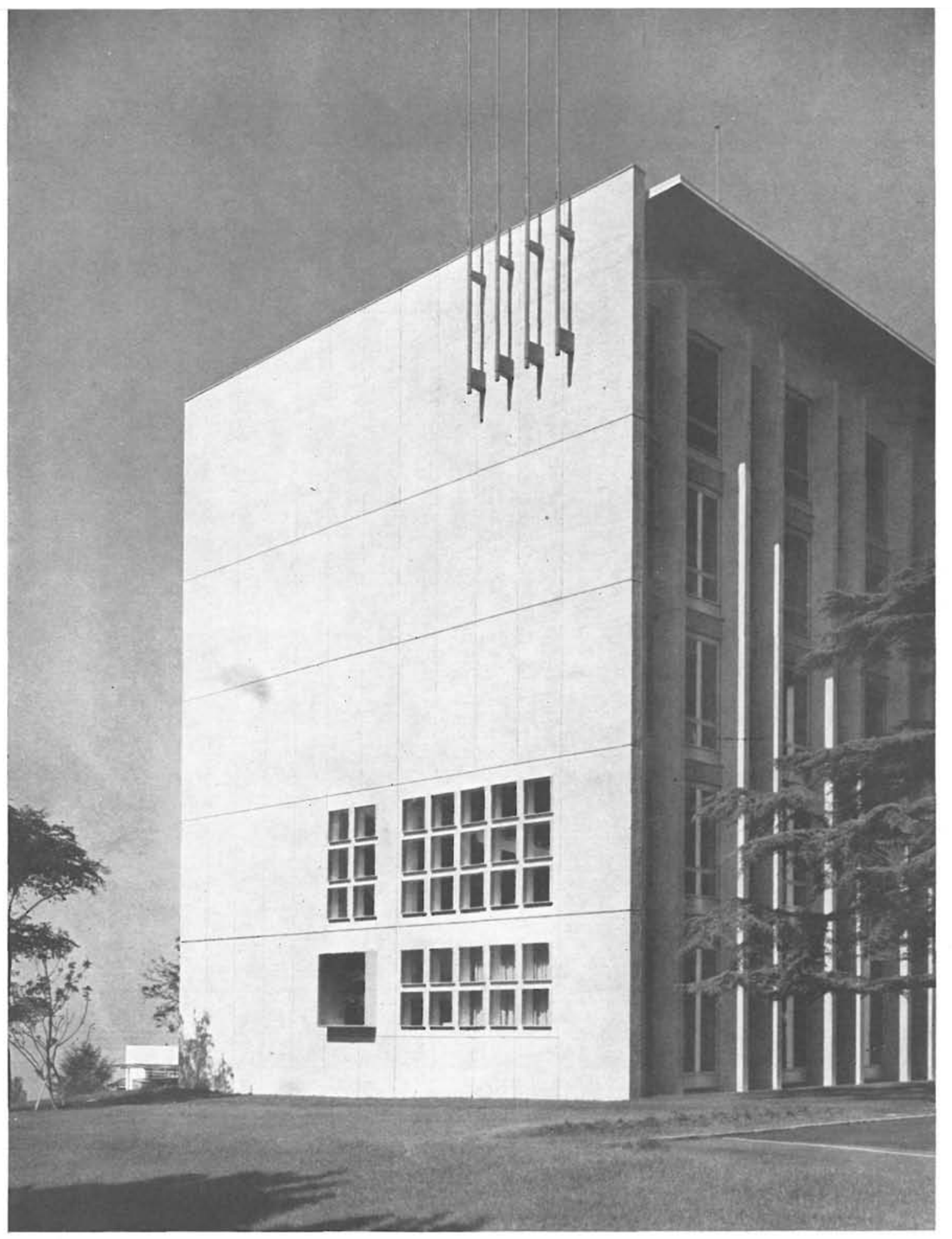

Una audaz marquesina se adelanta airosamente en la fachada norte para proteger al visitante que ha de salvar la distancia respetable que separa la avenida del edificio. Está construída con piezas de aluminio, de $5 \mathrm{~mm}$ de espesor, que adoptan forma de $\mathrm{V}$, recogiendo así las aguas de lluvia en el fondo. Se ha conseguido un elemento decorativo de gran belleza, pura línea y alarde técnico, dado que vuela libremente unos siete metros, cobijando la caja transparente y límpida de la entrada encristalada.

El hall principal, amplio y con crujías de mucha luz, permite la visión del gran lago, aun desde la propia calle, debido a la diafanidad de las fachadas norte y sur. Los materiales empleados son ricos: mármol suizo en el suelo, negro en el mostrador y serpentina en la escalera, de traza quizás algo pesada, pero jugando perfectamente con los fuertes pilares y el techo, en el cual se ha dibujado una composición de huecos tetraédricos en material acústico estriado y partes lisas del hormigón visto del forjado superior. 

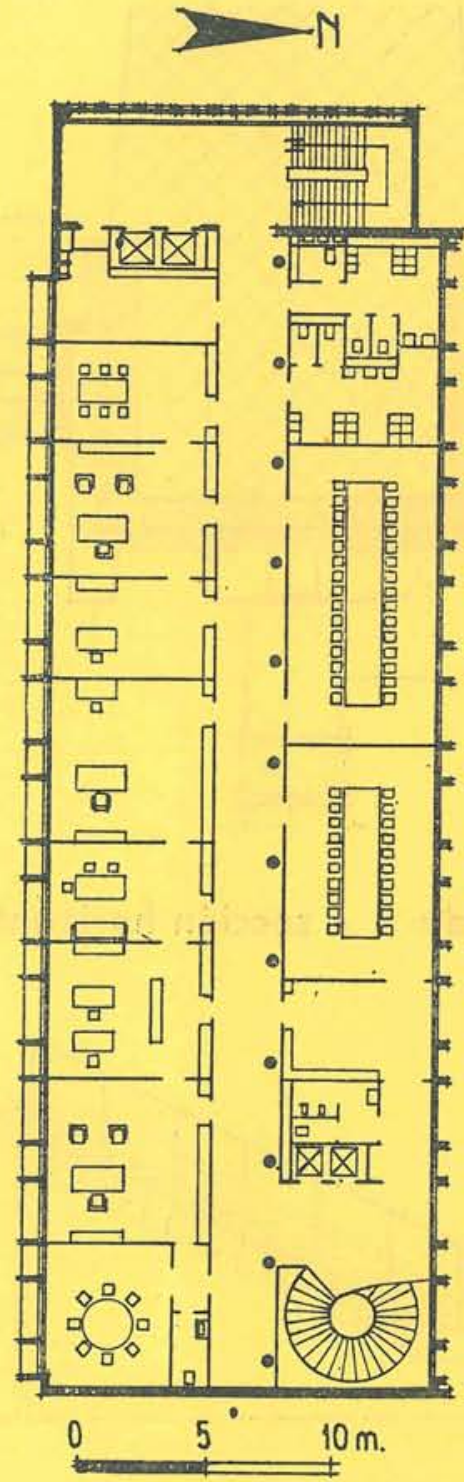

Hay un vestíbulo en la fachada occidental-iluminado por una retícula algo monótona, pero limpiamente estructurada-, al que se accede por una amplia escalinata de granito, y desde el cual parten la escalera secundaria y los ascensores. Otra escalera helicoidal conduce desde la planta baja a los locales de dirección.

Se ha procurado que la naturaleza viva participe, con su color y alegría, en la decoración interior, como continuación de la vegetación y del césped de la zona verde que rodea el ediflcio.

\section{planta y secciones}

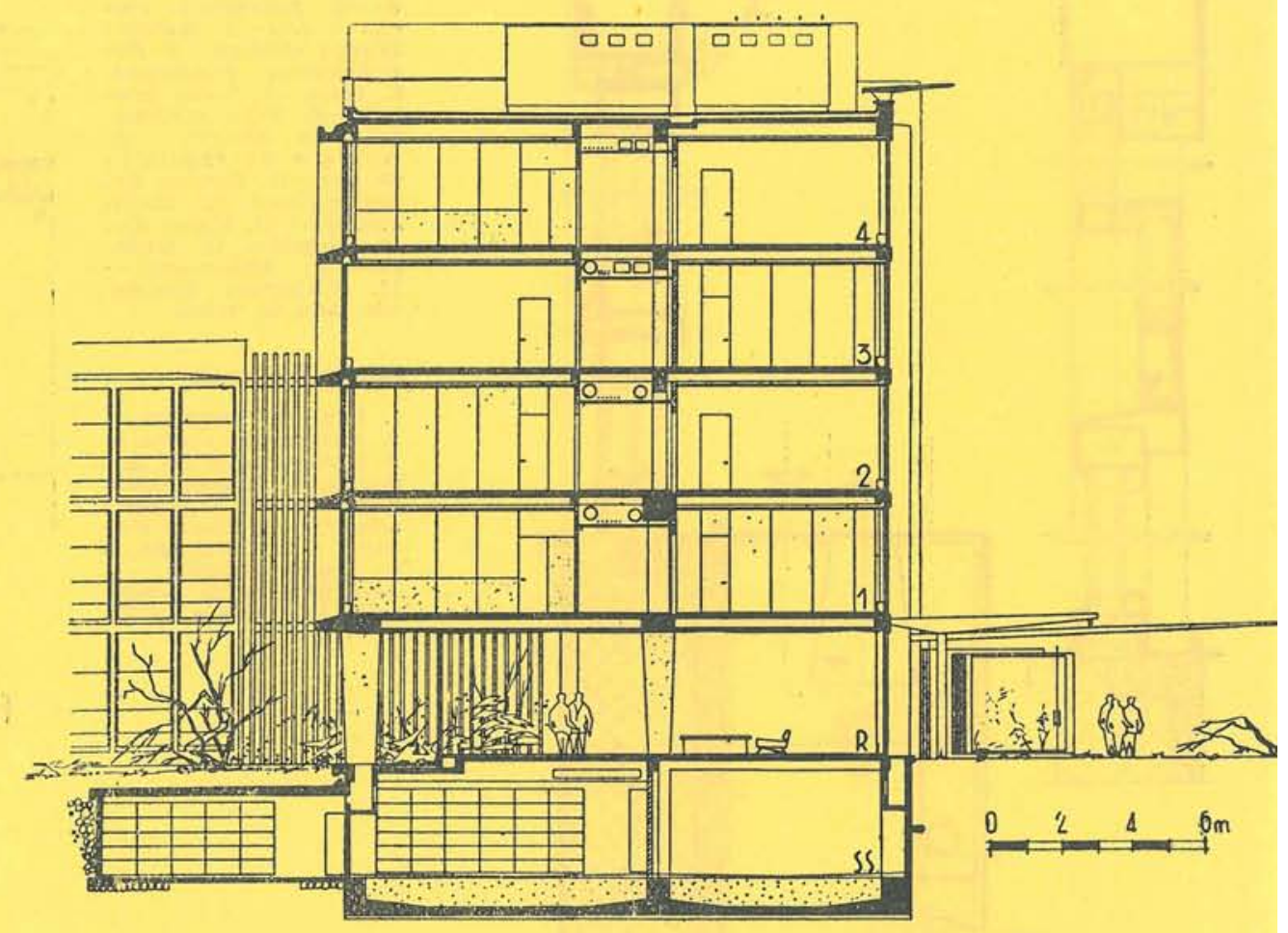

1. Hormigón armado.-2. Antepecho prefabricado.-3. Aislamiento corcho,-4. Revestimiento aluminio.-5. Revestimiento Plastofloor.-6. Chapa.-7. Toma de suelo de teléfono.-8. Tubo teléfono.-9. Tubo eléctrico.-10. Aparato de expulsión.-11. Llegada de aire caliente.-12. Marco giratorio.-13. Marco guillotina.-14. Persiana.-15. Madera.-16. Aislamiento--17. Cielorraso Frenger.-18. Renovacion del aire.-19. Aire para ventilación de las oficinas. -20 . Conductos acondicionamiento de aire ida y vuelta.-21. Tubos eléctricos. -22 . Tubo telefonico. -23 . Iluminación corredor. -24 . Placa yeso alrededor pilares. -25 . Tabiques móviles de cristal. -26 . Tabiques móviles opacos. -27. Armarios murales o estanterías.-28. Plinto aluminio.

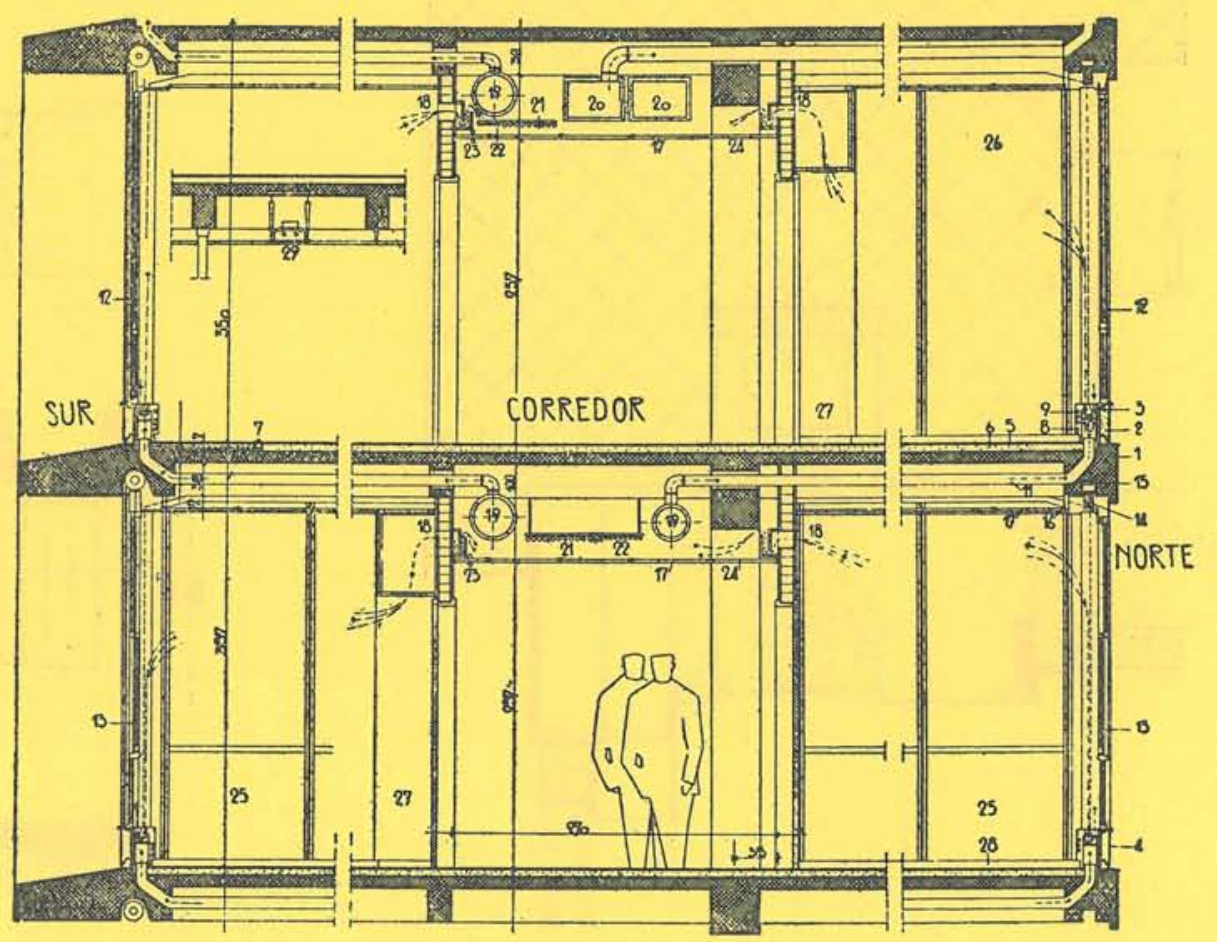

sección transversal del ala EO 


\section{detalles constructivos}

\section{cerramientos}
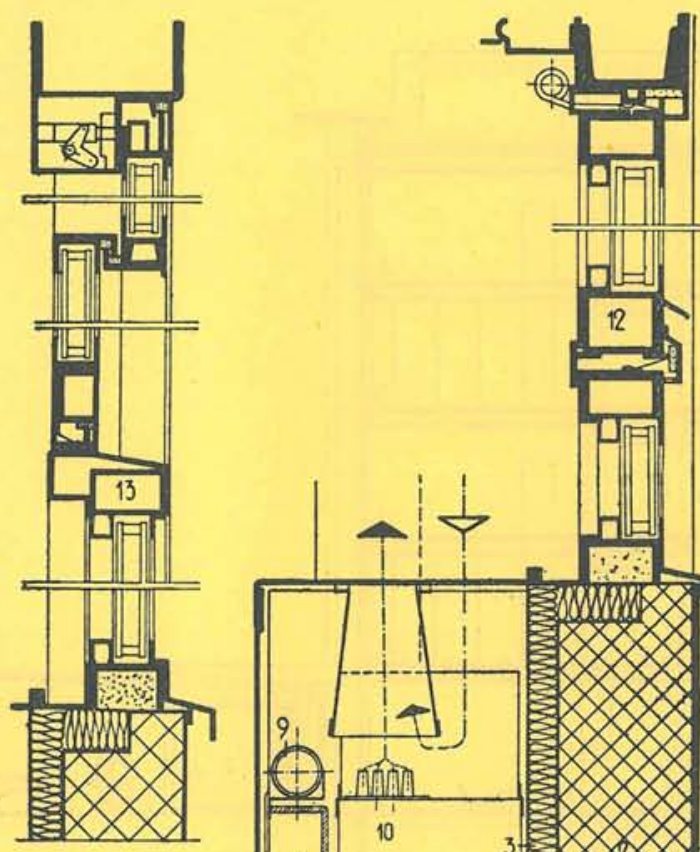

(1)


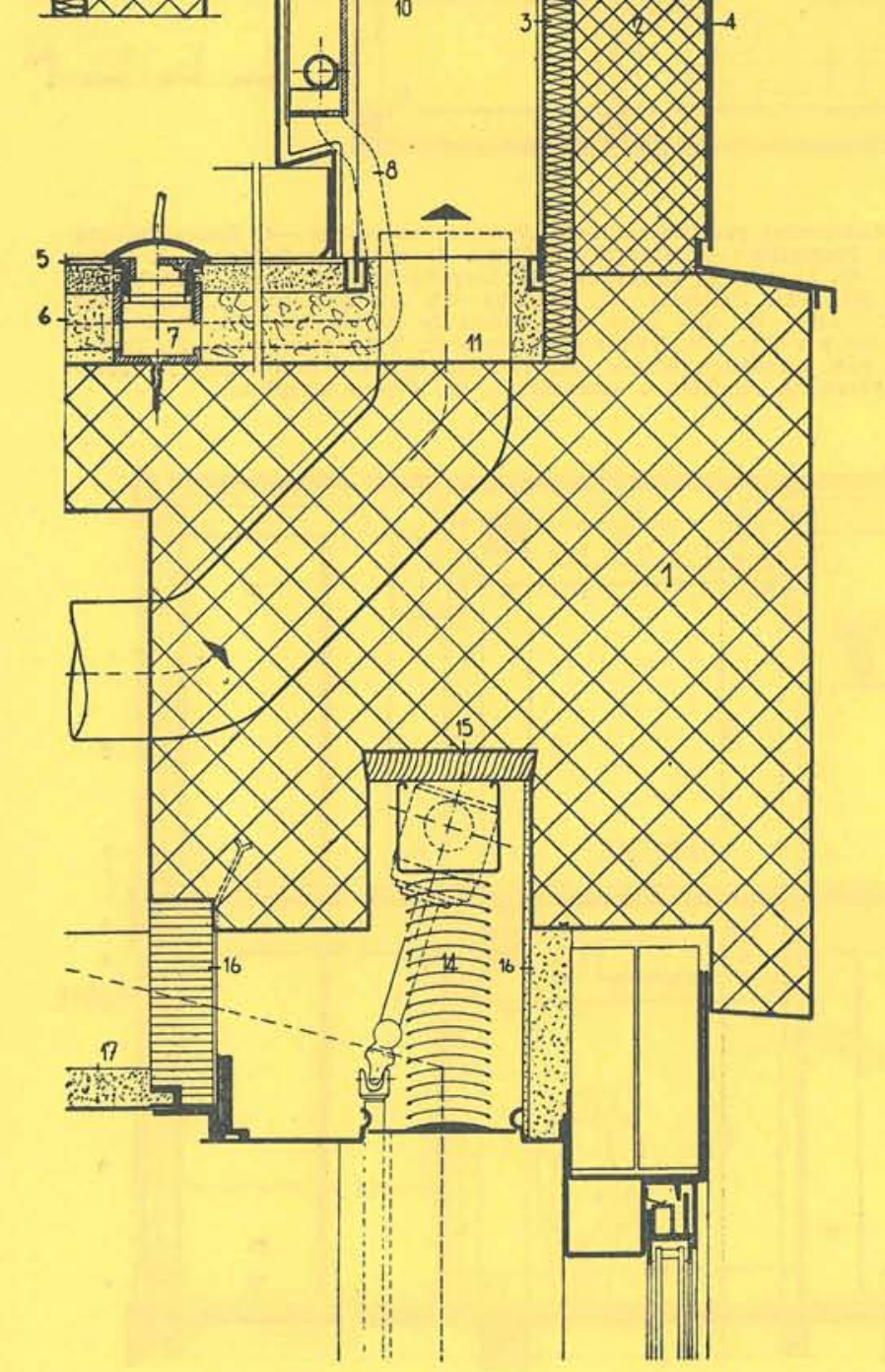

ventana fachada $\mathrm{N}$ - sección vertical

\section{seceión verfical}

1. Hormigón armado.2. Antepecho prefabricado.-3. Aislamiento corcho 2 cm. - 4. Revestimiento aluminio. - -5. Revestimiento Plastofloor. 6. Placa.-7. Toma telefono.-8. Tubo teléfono. 9. Tubo electrico. -10 . Aparato de expuision de aire.- 11 . Llegada del aire callente. - 12. Marco giratorio.-13. Marco fijo. 14. Persiana.-15. Made17. Cielorraso Frenger 17. Cielorraso Frenger con lana de vidrio.

\section{sección horizontal}

1. Pilar de hormigón. 2. Aislamiento corcho.-sianas. -4 . Revestimiento aluminio.-5. Antepecho aluminio.-6. Mando cortinón. - 7. Guillotina. 8. Marco giratorio, $-\overline{9}$. Laminillas de la persiana. - 10. Tabique móvil.

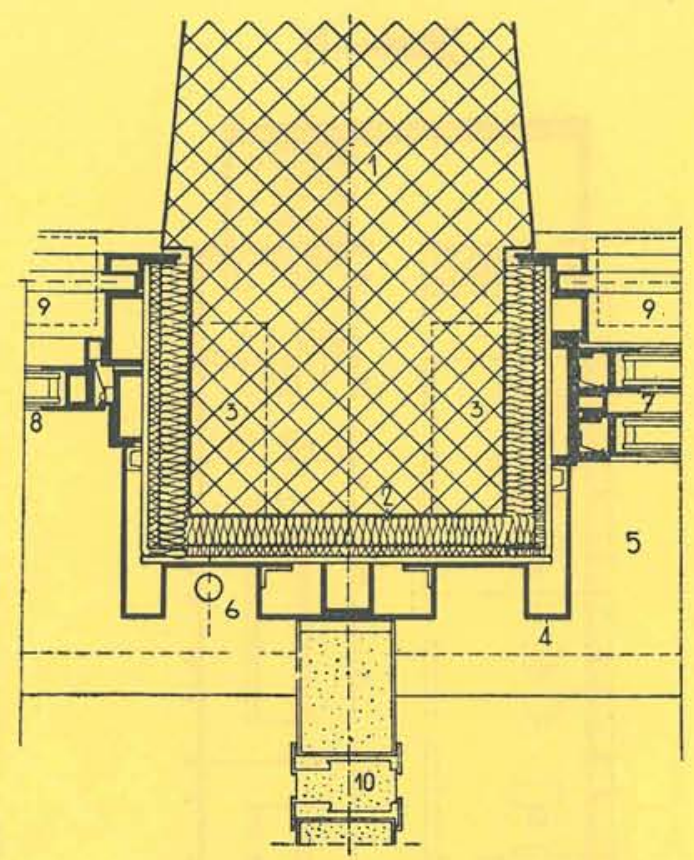

fachada S - sección horizontal
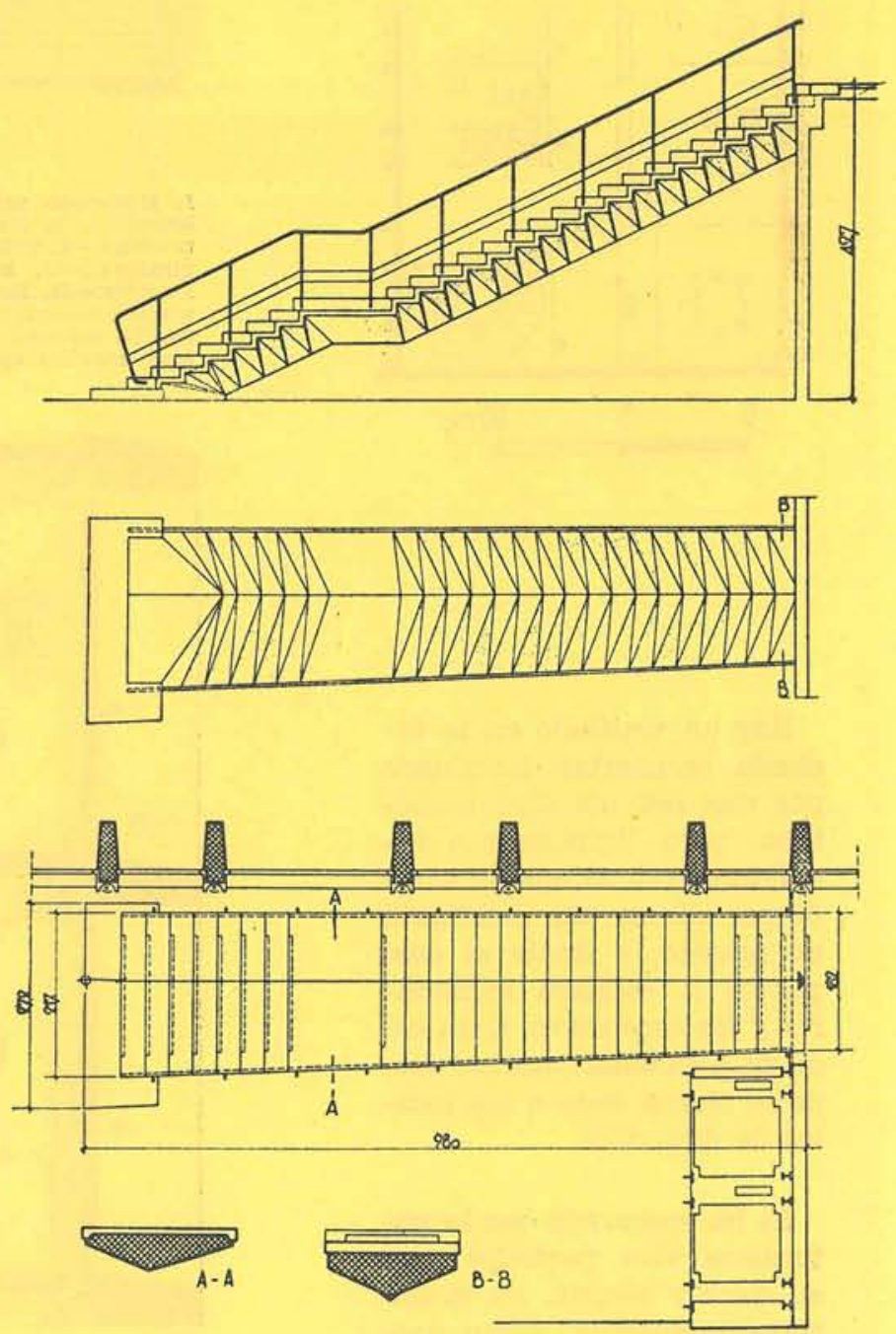

escalera principal 


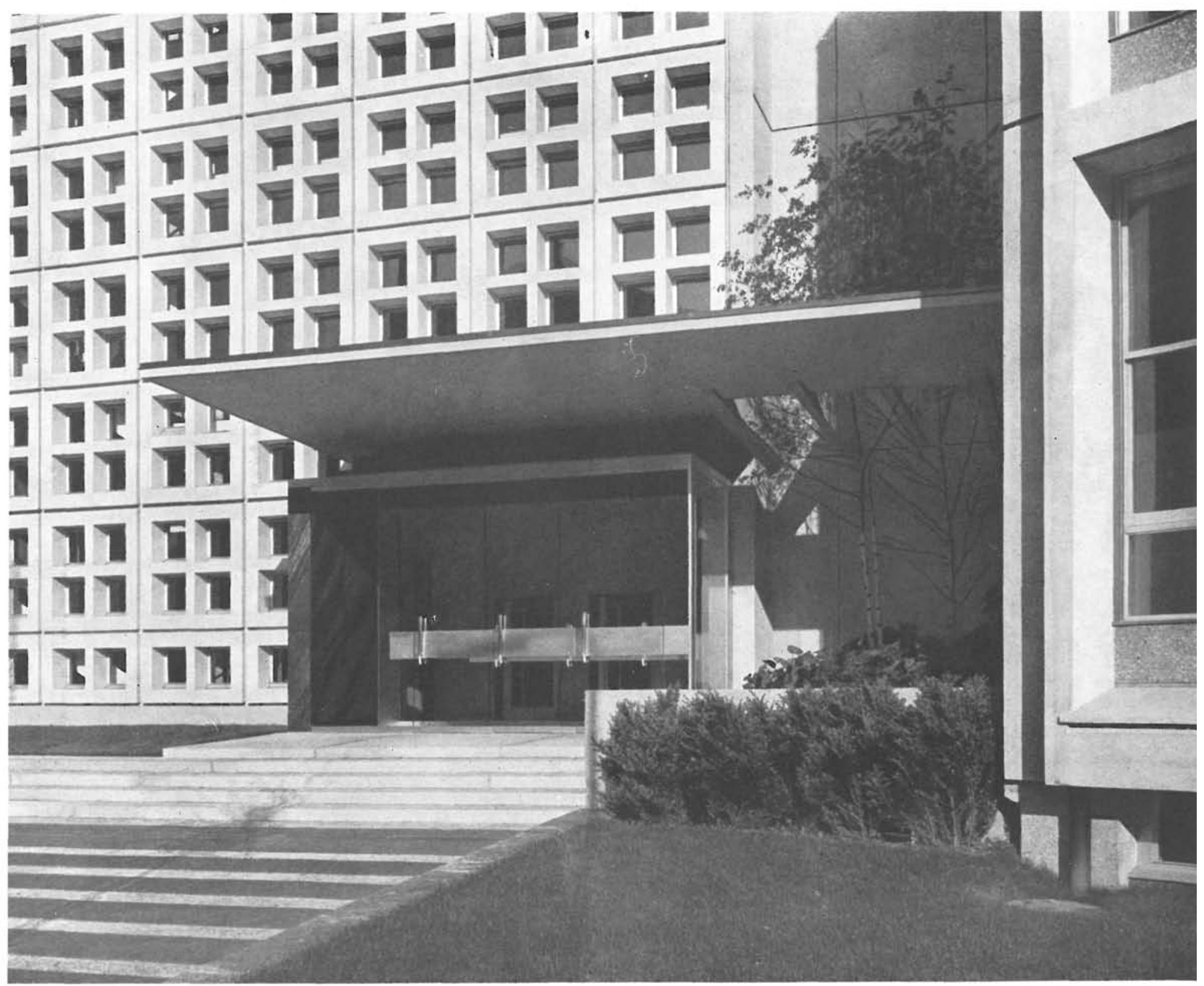

Las bases de composición han sido: la movilidad de tabiques para conseguir libertad de espacios; obtener una ventilación óptima, en salas donde trabajan unos cincuenta empleados, sin necesidad de abrir las ventanas, así como procurar que el encuentro de ambas alas proporcione los servicios fundamentales de distribución de personas y objetos (escaleras, ascensores y montacargas). 

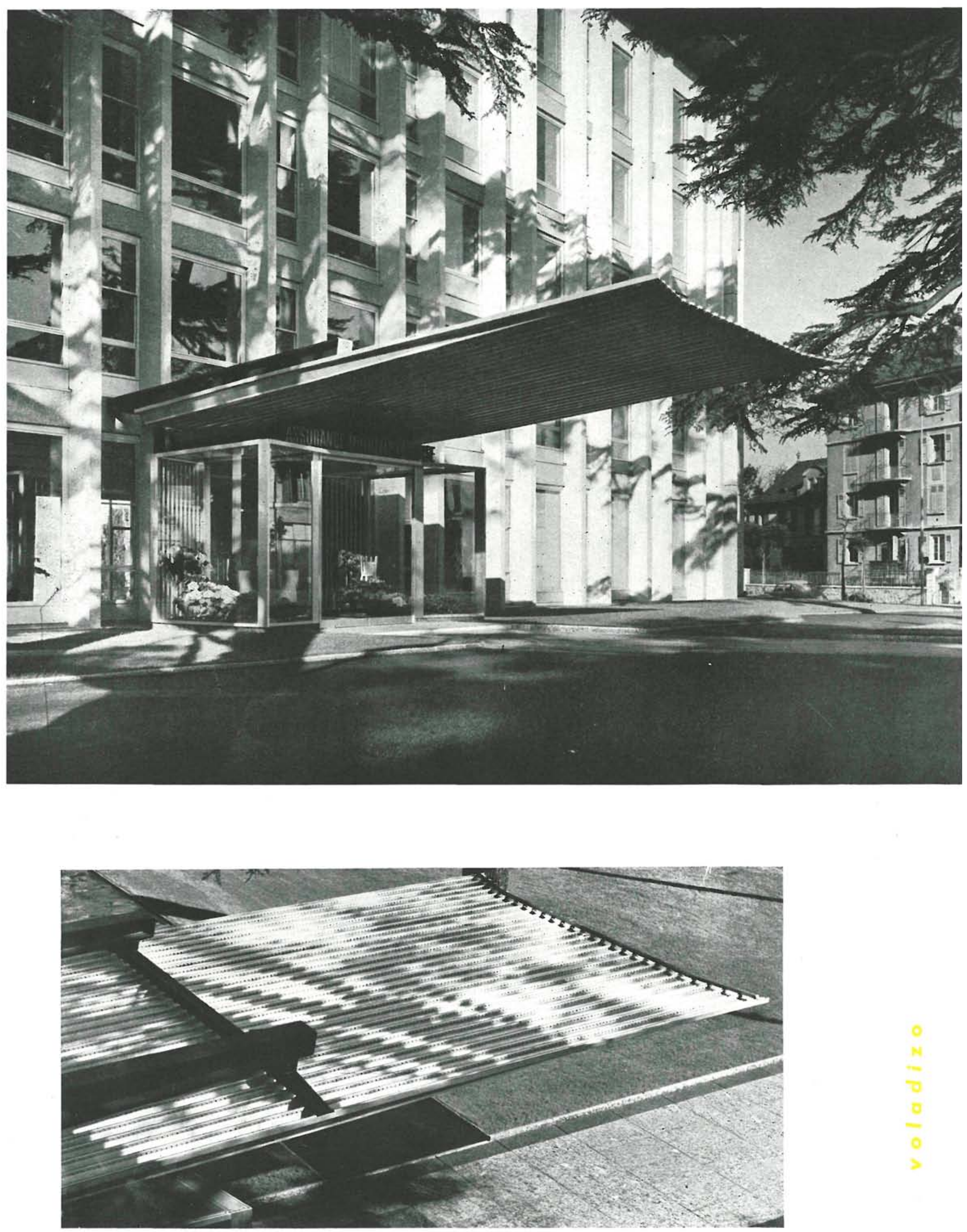


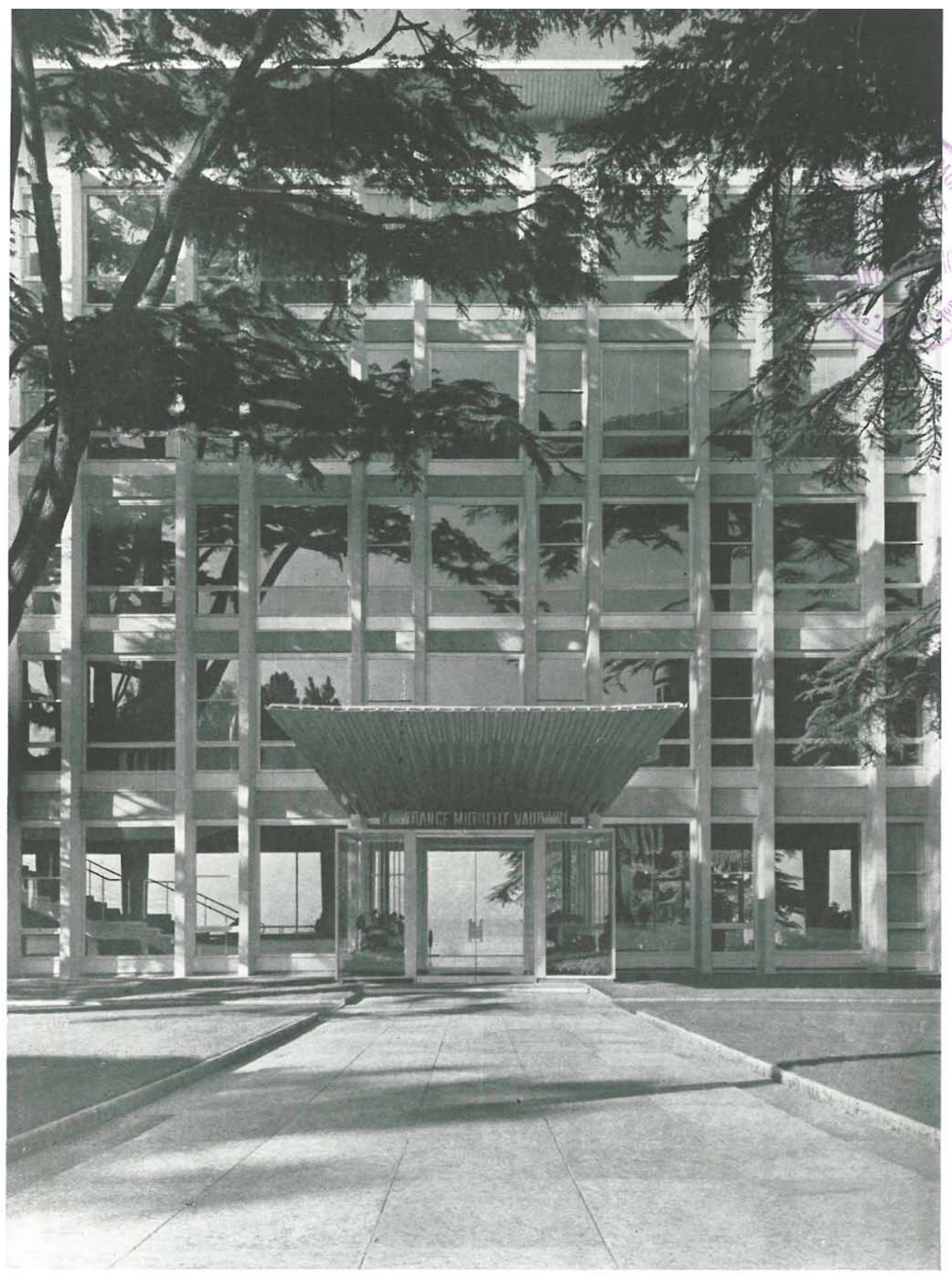

Entrada principal. 


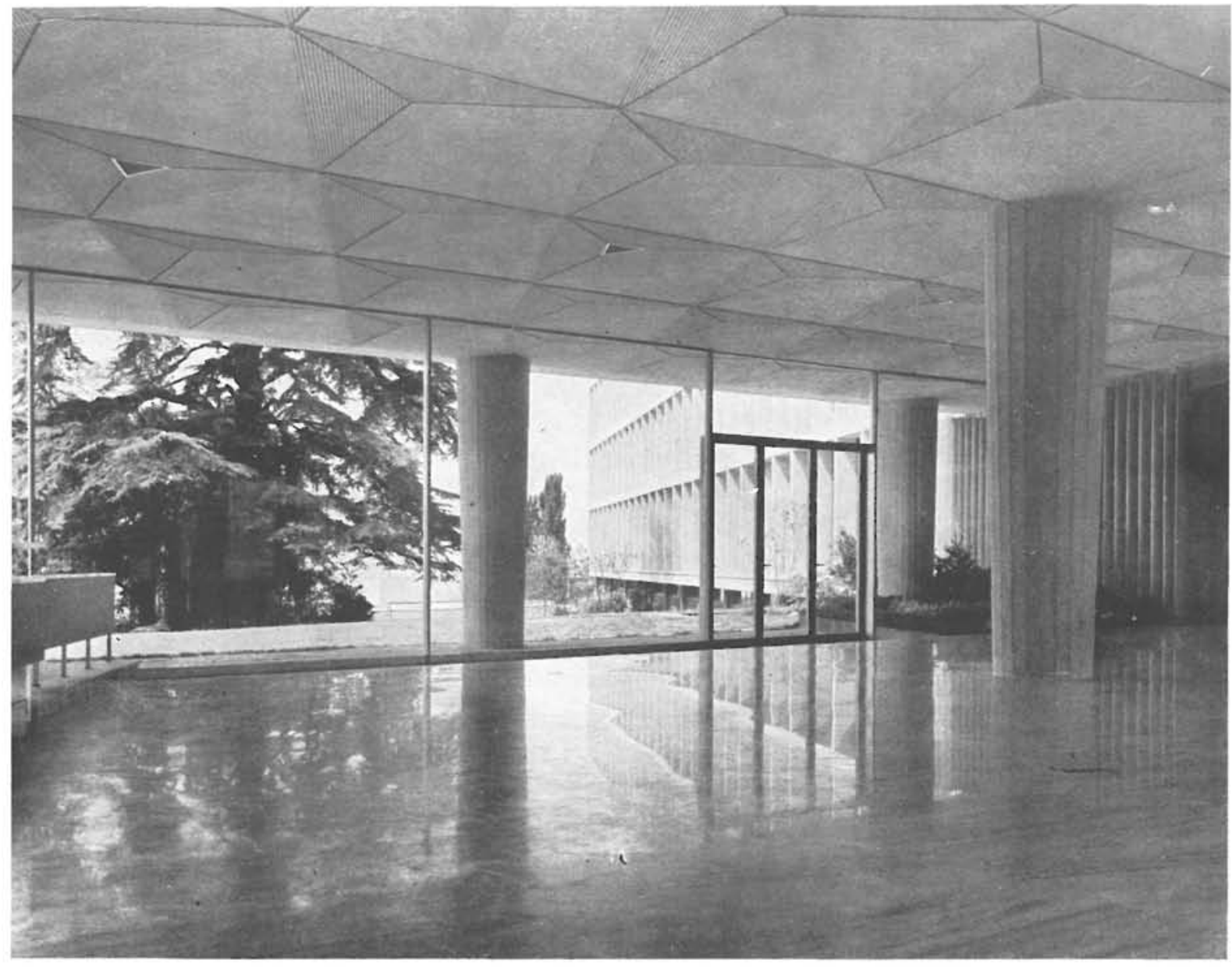

Hall principal.

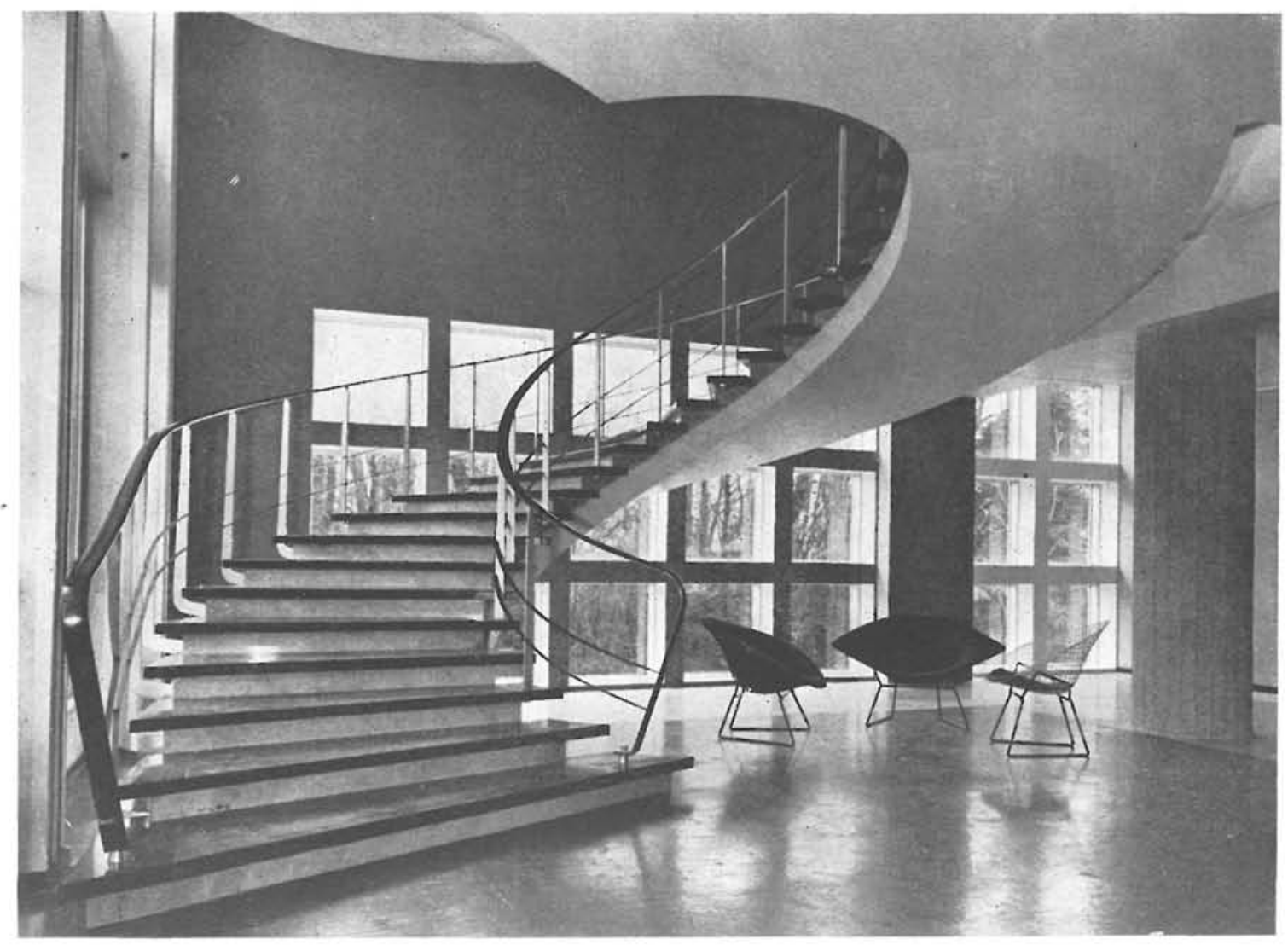

Escalera helicoidal, a dirección. 


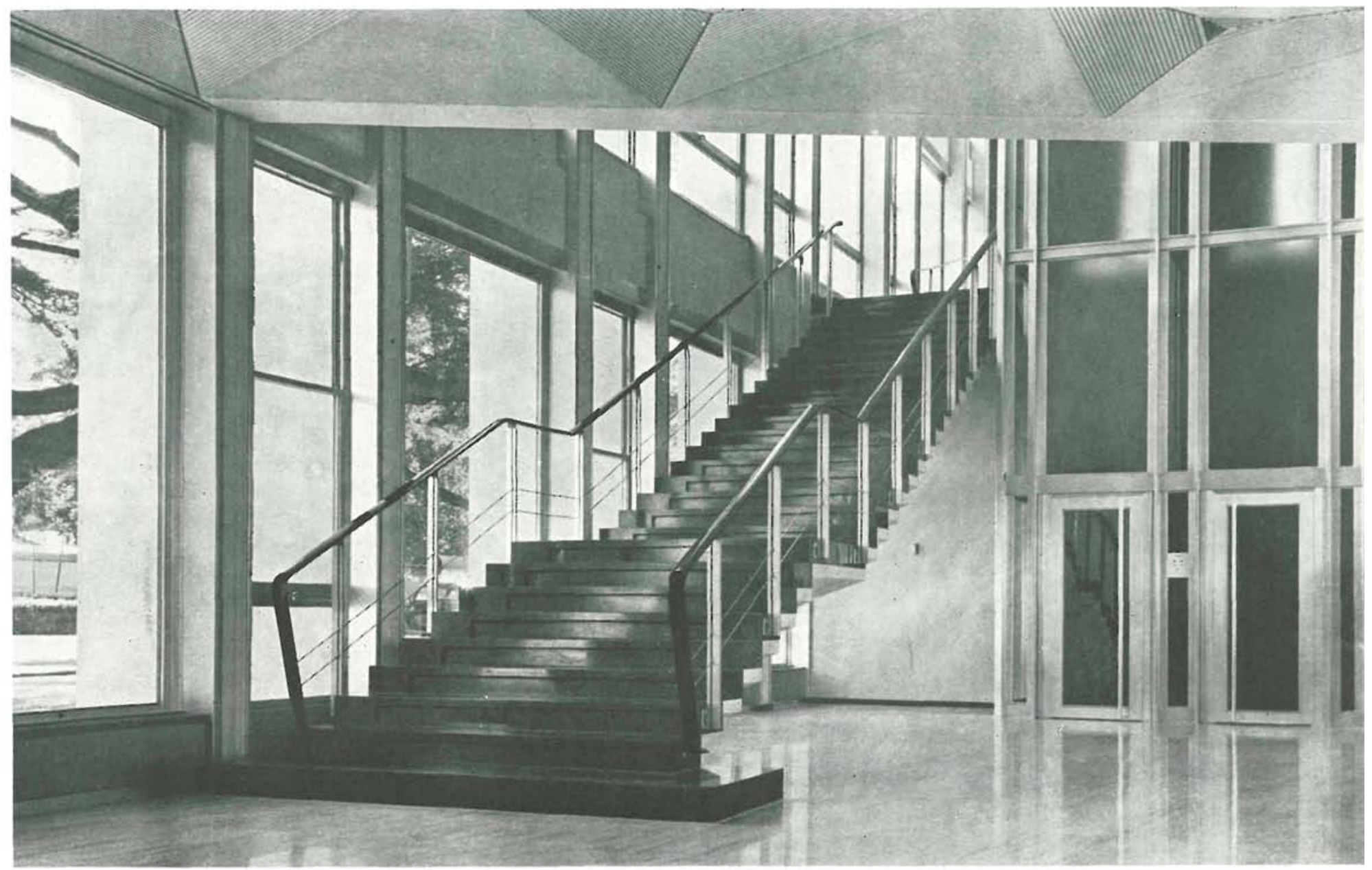

La estructura resistente es de hormigón armado y la cimentación por placa continua del mismo material, a causa de la desigual resistencia del terreno y la presencia de grandes cantidades de agua a poca profundidad.

Las fachadas se componen a base de retículas diversas, dejando visto el hormigón de cemento blanco en algunas ocasiones, o añadiendo un color verde delicado en otras, como ocurre con la fachada norte, con objeto de suavizar el contraste con el césped brillante y vivo, y el vibrante tono de los cedros.

Las ventanas tienen todas antepechos de aluminio muy bajos-tan sólo $30 \mathrm{~cm}$-, lo que permite, incluso a los empleados más alejados, contemplar el bello paisaje mediato e inmediato.

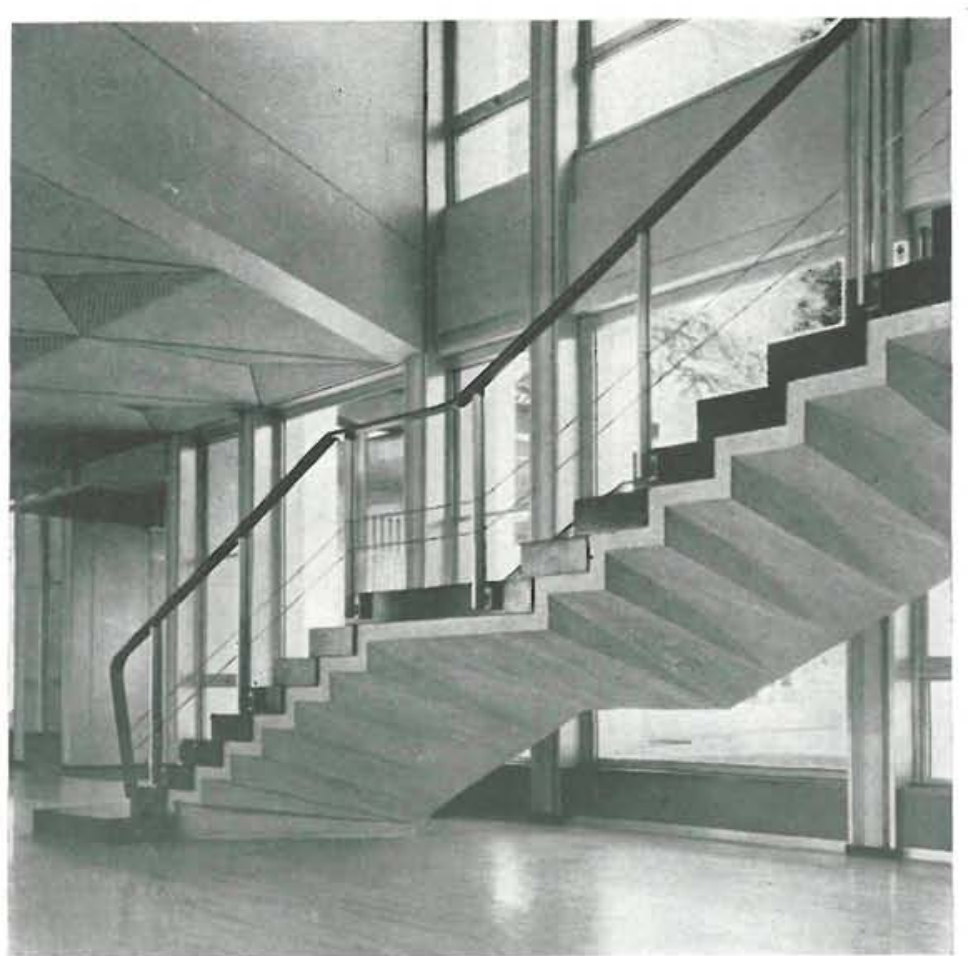



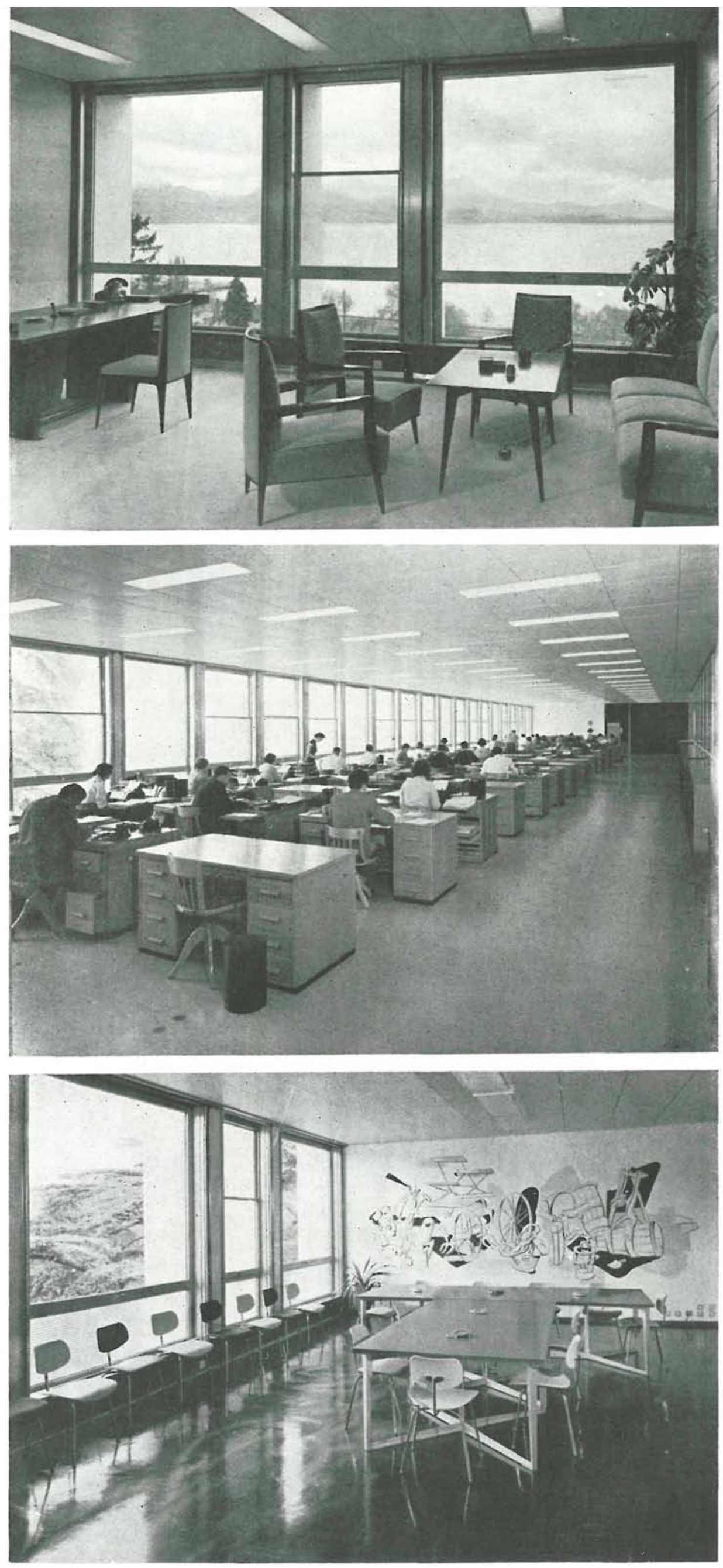

interiores

Hay persianas regulables para proteger de la acción del sol, y el acondicionamiento del sonido se consigue con placas acústicas de techo y suelos de goma.

El acondicionamiento climático de los locales y la iluminación natural o artificial son perfectos. Las instalaciones generales y la sala de mandos están en el sótano.

\section{Dirección.}

Oficinas.

Coloquios.

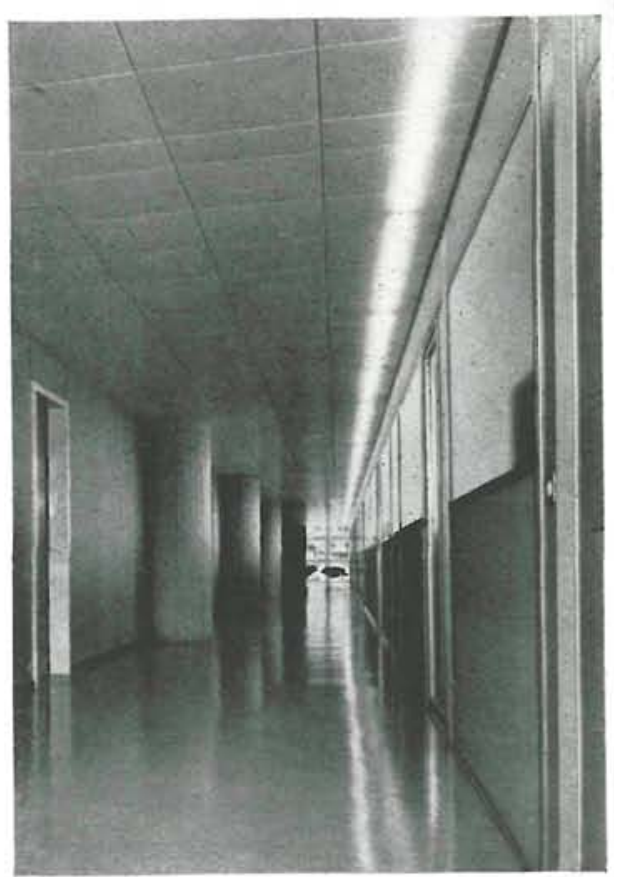

INFORMES DE LA CONSTRUCCION 89 


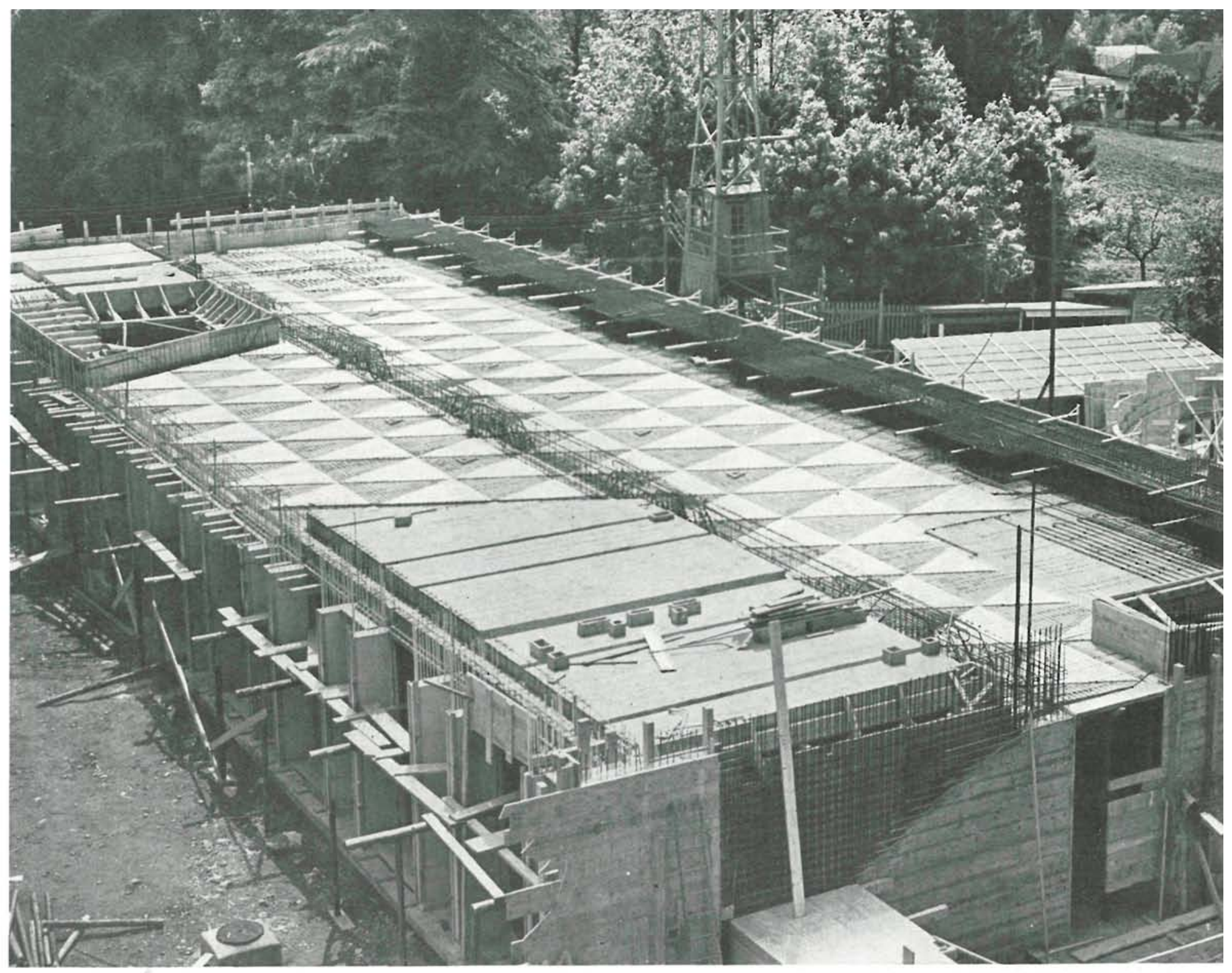

Un jardín suspendido sobre el ala occidental y una terraza sobre el brazo que se dirige hacia el E. proporciona maravillosas vistas de los alrededores. Se han estudiado, a conciencia, la policromía y el mobiliario, en sus partes y en el conjunto, para conseguir la armonía definitiva y un todo uniforme, grato y logrado.

INSTITUTO TECNICO DE LA CONSTRUCCION Y DEL CEMENTO

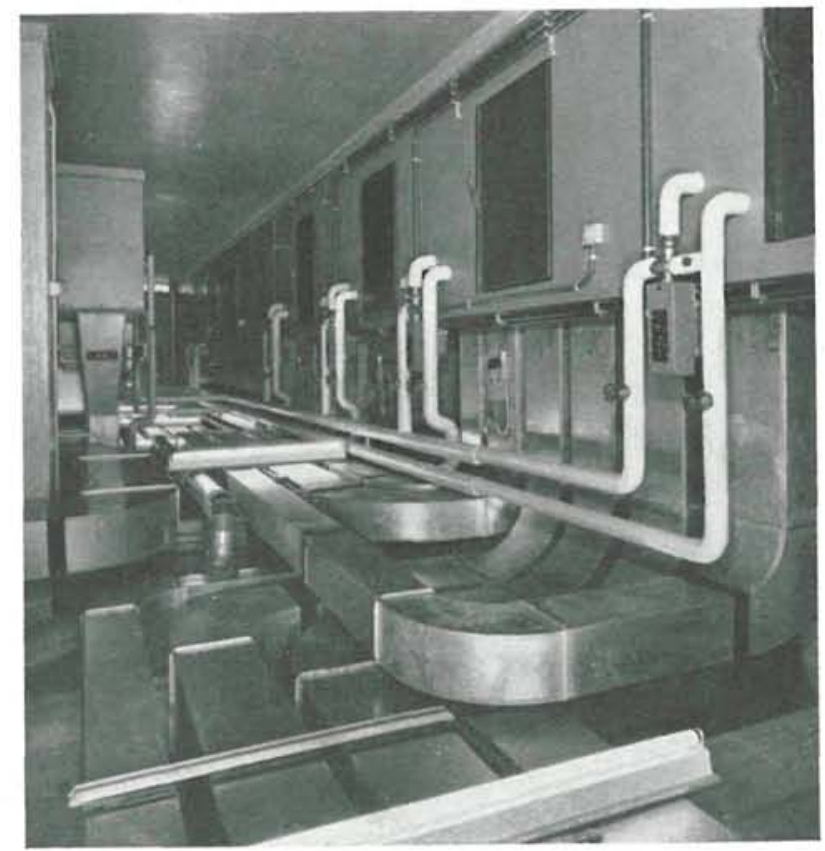

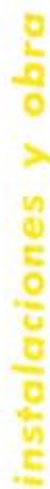



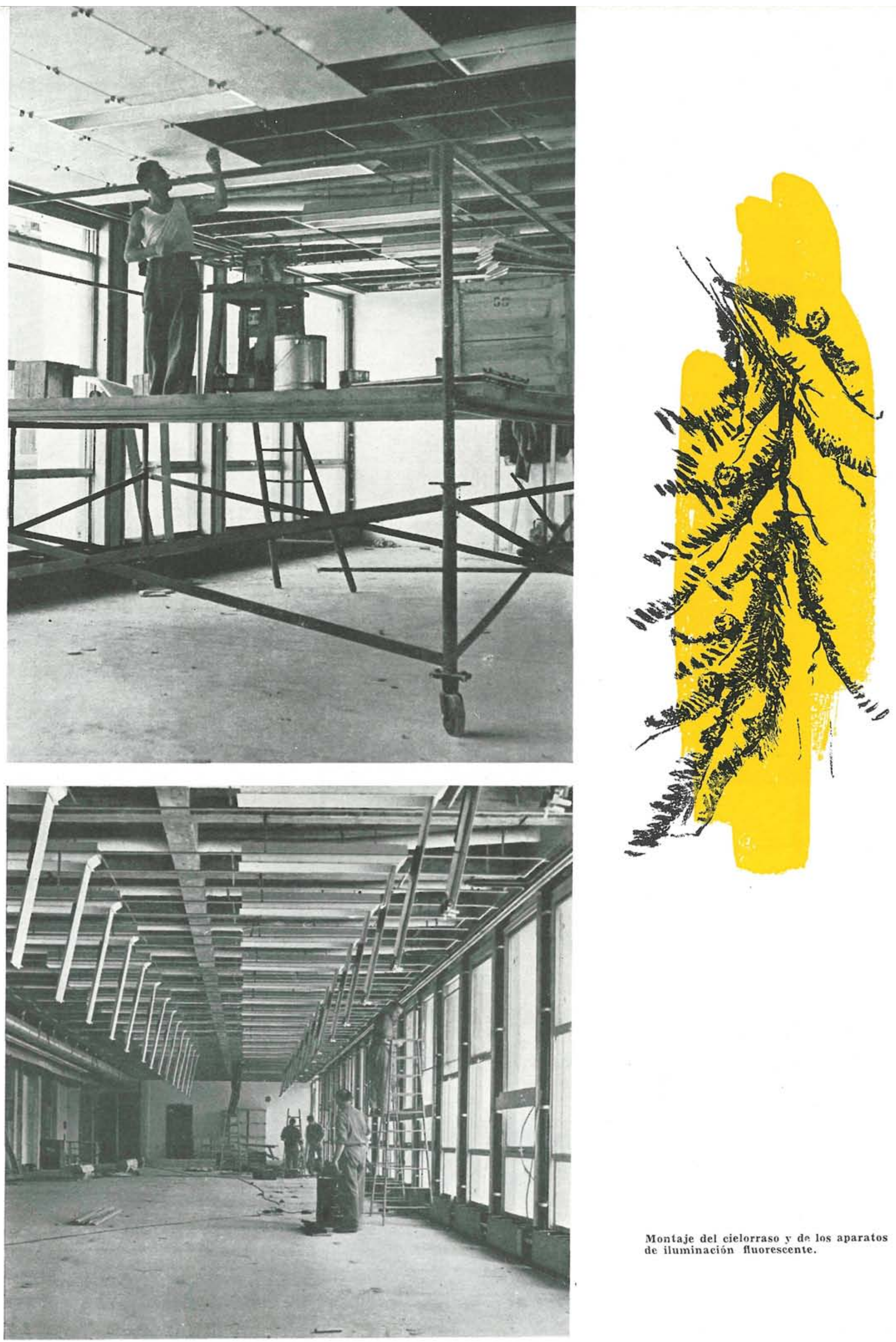

Montaje del cielorraso $y$ de 10 s aparatos de iluminación fluorescente. 